\title{
Determination of the carotenoid profile in peach fruits, juice and jam
}

\author{
Daniele GIUfFRIDA $^{1 *}$, Germana ToRRE ${ }^{2}$, Paola Dugo ${ }^{2,3}$, Giacomo Dugo ${ }^{1}$
}

\author{
${ }^{1}$ Dip. Sci. Ambient. Sicurezza \\ Territ. Aliment. Salut. \\ (SASTAS.), Univ. Studi \\ Messina, Viale Ferdinando \\ Stagno d'Alcontres, 31, \\ 98166 S. Agata, Messina, Italy \\ dgiuffrida@unime.it \\ 2 Univ. Messina, Fac. Farm., \\ Dip. Farm.-Chim., \\ Viale Annunziata, 98168, \\ Messina, Italy \\ ${ }^{3}$ Univ. Campus Bio-Med., \\ Via Álvaro del Portillo 21, \\ 00128 Rome, Italy
}

* Correspondence and reprints

Received 17 December 2011 Accepted 15 March 2012

Fruits, 2013, vol. 68, p. 39-44 (C) 2012 Cirad/EDP Sciences All rights reserved DOI: $10.1051 /$ fruits/2012049 Www.fruits-journal.org

RESUMEN ESPAÑoL, p. 44

\section{Determination of the carotenoid profile in peach fruits, juice and jam.}

Abstract - Introduction. Carotenoids have been described as possessing several important functional properties and health benefits. These properties make these compounds ideal for the always increasing functional food industry as well as for promoting the consumption of the natural products in which they are contained. Here, we report the first characterisation of the non-saponified carotenoid composition in fresh peach fruits and commercial peach juice and jam. Materials and methods. Fully mature yellow-fleshed peach fruits produced in Sicily were purchased at a local market; they were peeled and the pulp was analysed. Commercial peach juice and commercial peach jam from three different known manufacturers were also purchased at the local market. Both the juice and jam analysed were produced by local manufacturers from the same kind of fresh fruit studied in this work. After carotenoid extraction with organic solvents, the samples were analysed by a direct HPLC-DAD-APCI-MS methodology. Results and discussion. Three free carotenoids (zeaxanthin, $\beta$-cryptoxanthin and $\beta$-carotene) and three monoesters of $\beta$-cryptoxanthin were identified and detected in all the samples analysed. Interestingly, the carotenoid profile remained the same in all the samples, and it was not affected by the peach processing occurring during the production of the peach juice and jam. Moreover, small differences were observed in the relative contents of the identified components among the samples investigated.

Italy / Prunus persica / peaches / fruit juices / jams / chromatography / proximate composition / carotenoids

\section{Détermination du profil des caroténoïdes dans le fruit, le jus et la confiture de pêche.}

Résumé - Introduction. Les caroténoïdes ont été décrits comme ayant plusieurs importantes propriétés fonctionnelles et des effets positifs sur la santé. Ces propriétés rendent ces composés idéaux pour l'industrie alimentaire fonctionnelle sans cesse grandissante ainsi que pour la promotion de la consommation des produits naturels dans lesquels ils entrent. Nous reportons ici la première caractérisation de la composition des caroténoïdes non saponifiés dans les pêches fraîches et dans les jus et confiture de pêche commerciaux. Matériel et méthodes. Des pêches jaunes en pleine maturité produites en Sicile ont été achetées sur le marché local ; elles ont été pelées puis leur pulpe a été analysée. Du jus et de la confiture de pêche d'origine commerciale provenant de trois différentes fabriques connues ont également été achetés au marché local. Le jus et la confiture analysés ont été produits par des fabricants locaux à partir du même type de fruits que les fruits frais étudiés par ailleurs. Après extraction des caroténoïdes à l'aide de solvants organiques, les échantillons ont été analysés par une méthode directe de HPLC-DAD-APCI-MS. Résultats et discussion. Trois caroténoïdes libres (zéaxanthine, $\beta$-cryptoxanthine et $\beta$-carotène) et trois monoesters de $\beta$-cryptoxanthine ont été identifiés et détectés dans tous les échantillons analysés. Fait intéressant, le profil des caroténoïdes est resté le même dans tous les échantillons et il n'a pas été affecté par la transformation des fruits lors de la production du jus et de la confiture de pêche. En outre, de petites différences ont été observées dans les teneurs relatives des composants identifiés dans les échantillons étudiés.

Italie / Prunus persica / pêche (fruits) / jus de fruits / confiture / chromatographie / composition globale / caroténoïde 


\section{Introduction}

Stone fruits play an important role in human health due to the range of phytonutrients they contain. Fresh peaches are economically and nutritionally important because during the spring and summer months they may become a significant part of the fruits which we consume in our diet. Moreover, peach juice and jam are continually consumed throughout the year. Italy is the first country in Europe and the second in the world, after China, for peach production; in Italy, a per capita annual peach consumption of $11 \mathrm{~kg}$ is estimated.

Carotenoids have been described as possessing several important functional properties and health benefits [1], mainly antioxidant activity [2, 3], as well as prevention of cardiovascular diseases [4, 5], cancer [6] and macular degeneration [7, 8] and, in some cases, provitamin A activity. These properties make these compounds ideal for the always increasing functional food industry as well as promoting the consumption of the natural products in which they are contained. The chemical structure of carotenoids is usually based on a $\mathrm{C}_{40}$ tetraterpenoid moiety with a centrally located, extended conjugated double bond system, which acts as the light-absorbing chromophore. Taking into account their chemical structure, these compounds can be divided into two different groups: firstly, hydrocarbon carotenoids, generally named carotenes; and oxygenated carotenoids, commonly known as xanthophylls. This second group is the most complex one in terms of number of compounds and variations in their structure, and it can be found in either its free form (like the carotenes) or in a more stable fatty acid esterified form in the case of mono- and polyhydroxylated xanthophylls. Thus, in view of the fact that a single carotenoid could be found forming different esters, the already complex natural variability of carotenoids is often increased by the formation of these carotenoid esters. For this reason, to simplify the analysis of these compounds, phytonutrients such as xanthophylls have most frequently been analysed after a saponification step, which releases the free xanthophylls, thus losing information about the native composition of the matrix; moreover, during the saponification step, degradation and artifact formation of the carotenoids may occur.

The study of intact carotenoid (samples without saponification) composition could be a useful tool to increase the information about the carotenoids naturally found in the various matrices and the relationships between them, and could also be used to establish authenticity markers that could potentially be used to prevent adulterations. The correct characterisation of these compounds is necessary to obtain reliable compositional data for realistic and valuable conclusions in nutritional studies. The first characterisation of the native carotenoid composition in fresh peach fruits and commercial peach juice and jam, obtained by direct HPLC-DAD-APCI-MS analysis, is reported in this study.

In the literature, there is a limited number of reports on peach fruits' saponified carotenoid content [9-12], and only one report which also considered the carotenoids in fresh, canned and dried peach samples [13]. There are no reports on the carotenoid content in peach juice and jam. The aim of our work was to provide the first study relative to the determination of the non-saponified carotenoid profile in peach fruits and commercial peach juice and jam, by applying a direct HPLC-DAD-APCI-MS methodology using a C30 column.

\section{Materials and methods}

\subsection{Chemicals}

All the reagents and solvents used were of analytical or HPLC grade and were purchased from Sigma-Aldrich (Milan, Italy). Carotenoid standards, namely, $\beta$-carotene, lycopene, $\beta$-cryptoxanthin, lutein, zeaxanthin, lutein dipalmitate and physalein, were purchased from Extrasynthese (Genay, France) 


\subsection{Sample collection}

Fully mature yellow-fleshed peach fruits produced in Sicily were purchased at a local farmers' market in three different lots of $5 \mathrm{~kg}$ each; they were peeled and the pulp was analysed immediately after arrival in the laboratory. The fruits were a mixture of different varieties, mainly 'Maravilla', 'O'Henry' and 'Summerset'. Commercial peach juice and commercial peach jam from three different known local manufacturers were also purchased at a local farmers' market, respectively, in three different lots of five juice bottles and five jams. Both the juice and jam analysed were produced by local manufacturers from the same type of fresh fruit studied in this work. The storage time of both juice and jam was 6 months.

\subsection{Carotenoid extraction}

The samples (aliquots of fresh fruits $370 \mathrm{~g}$, juice $31 \mathrm{~g}$, jam $50 \mathrm{~g}$ ) were homogenised, and were completely extracted with $100 \mathrm{~mL}$ of a mixture of methanol / ethyl acetate / petroleum ether $(1: 1: 1, \mathrm{v} / \mathrm{v} / \mathrm{v})$ containing butylated hydroxytoluene (BHT) as an antioxidant. The extract was washed successively with water, diethyl ether and $\mathrm{NaCl}$ saturated solution. The ether phase was evaporated using a Rotavapor at $35^{\circ} \mathrm{C}$. The residue was dissolved in $\mathrm{MeOH} / \mathrm{MTBE}$ $(1: 1 \mathrm{v} / \mathrm{v})$ prior to the HPLC analysis. Samples were stored at $-20{ }^{\circ} \mathrm{C}$ until they were analysed. The study of recovery of zeaxanthin, $\beta$-cryptoxanthin and $\beta$-carotene, by the extraction procedure from the peach fruits using the standard technique of enrichment, was $92 \%$ for zeaxanthin, $91 \%$ for $\beta$-cryptoxanthin and $97 \%$ for $\beta$-carotene.

\subsection{HPLC-DAD-APCI-MS analysis}

The analyses were carried out on an HPLC system (Shimadzu, Milan, Italy) equipped with a CBM-20A controller, two LC-20AD pumps, a DGU-20A 3 degasser, a SIL-20AC autosampler and a SPD-M20A photodiode array detector. The data were processed with the software Labsolution ver. 5.10.153 (Shimadzu). For MS analyses a mass spectrometer detector (LCMS-2020, Shimadzu) was used, equipped with an APCI interface, both in positive and negative ionisation mode. Separations were performed on a YMC C30 column $(250 \mathrm{~mm} \times 4.6 \mathrm{~mm}, 5 \mu \mathrm{m}$ particles); the mobile phases consisted of methanol / MTBE / water (83:15:2, v / v / v; eluent A) and methanol / MTBE / water (8:90:2, v / v / v; eluent B), using a gradient program as follows: $0 \mathrm{~min} 0 \% \mathrm{~B} ; 20 \mathrm{~min}$ 0\% B; 160 min 100\% B; 161 min 0\% B. The flow rate was $0.8 \mathrm{~mL} \cdot \mathrm{min}^{-1}$ and the injection volume was $20 \mu \mathrm{L}$. The UV-Vis spectra were acquired in the range of $250-600 \mathrm{~nm}$, while the chromatograms were extracted at $450 \mathrm{~nm}$ (sampling frequency: $1.5625 \mathrm{~Hz}$; time constant: $0.64 \mathrm{~s}$ ). The MS was set as follows: scan, both APCI positive $(+)$ and negative $(-)$; nebulising gas flow $\left(\mathrm{N}_{2}\right)$ : $4.0 \mathrm{~L} \cdot \mathrm{min}^{-1}$; event time: $1 \mathrm{sec}$; detector voltage: $0.8 \mathrm{kV} ; \mathrm{m} / \mathrm{z}$ range: $350-1200$; interface voltage: $4.5 \mathrm{kV}$; interface temperature: $350^{\circ} \mathrm{C}$; CDL voltage: $0 \mathrm{~V}$; CDL temperature: $300{ }^{\circ} \mathrm{C}$; heat block: $300{ }^{\circ} \mathrm{C}$; Q-array: $0.0 \mathrm{~V}$; RF: $90 \mathrm{~V}$; sampling: $2 \mathrm{~Hz}$. Samples were analysed in triplicate. Quantitation was performed using the external standards method, performed after the preparation of a five-point external standard calibration curve of each available standard; standard calibration curve $R^{2}$ values were in the range of $0.9991-0.9995$.

\section{Results and discussion}

In extracts of fresh peach fruits, commercial peach juice and commercial peach jam, three free carotenoids, zeaxanthin, $\beta$-cryptoxanthin and $\beta$-carotene, and three monoesters of $\beta$-cryptoxanthin were identified and detected in all the samples analysed. Interestingly, the carotenoid profile remained the same in all the samples, and was not affected by the peach processing occurring during the production of the peach juice and jam (figure 1).

Compounds were identified by comparison with the available standards, by their UV-vis spectra and by their MS spectra recorded in both positive and negative APCI ionisation modes (table I). As far as detection is concerned, the combination of 
Figure 1.

Chromatogram $(450 \mathrm{~nm})$ of the carotenoids in fresh peach fruit, peach juice and peach jam using a C30 column.
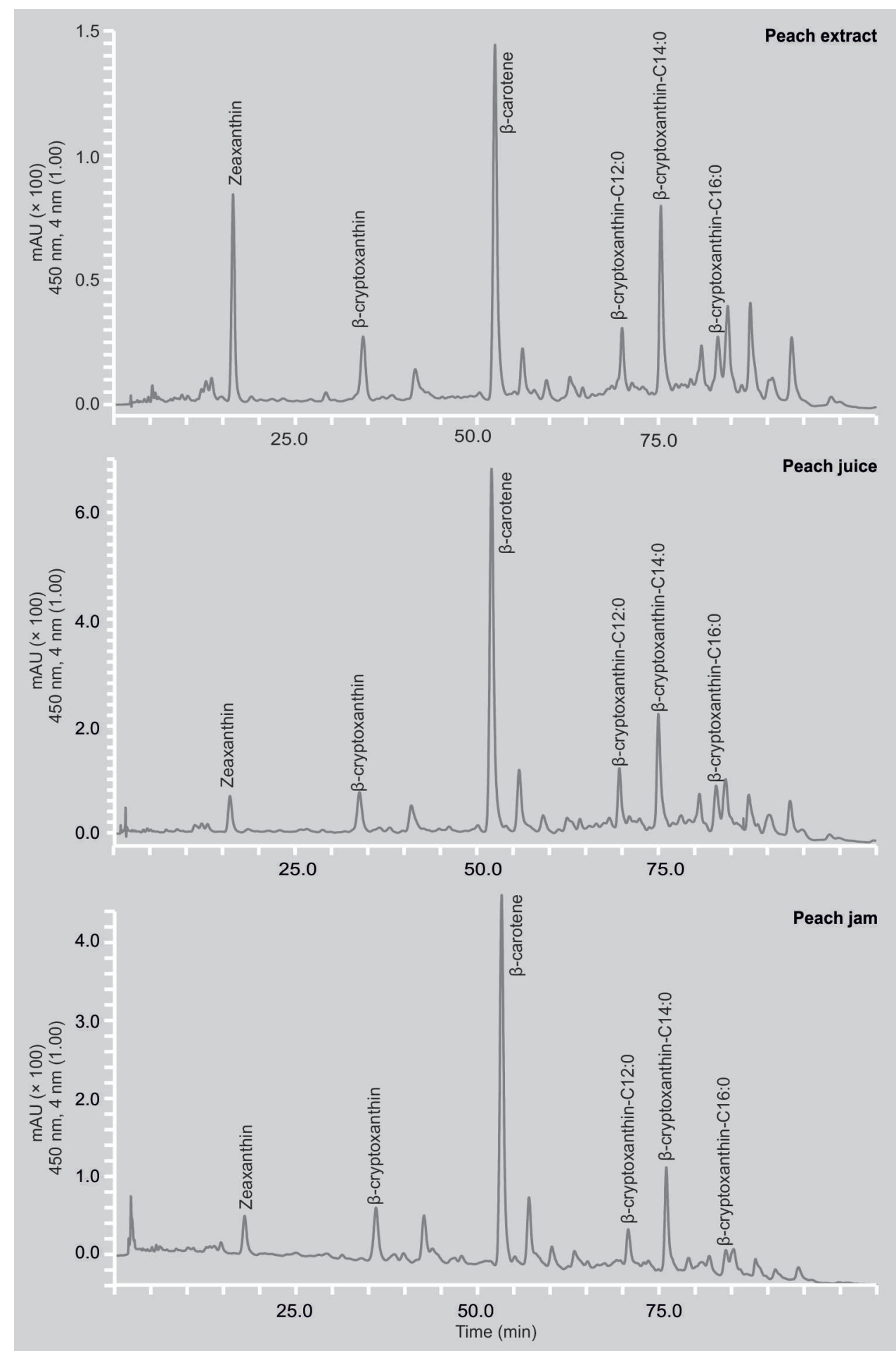

PDA and MS is mandatory if unambiguous structure assignment is desired, since it results in quite overlapping UV spectra [14]. Moreover, small differences were observed in the relative contents of the identified 
Table I.

UV-vis and $\mathrm{MS} \mathrm{APCl} \mathrm{(+)} \mathrm{and} \mathrm{APCl} \mathrm{(-)} \mathrm{information} \mathrm{on} \mathrm{the} \mathrm{carotenoids} \mathrm{identified} \mathrm{in}$ fresh peach fruit extract, and in commercial peach juice and jam.

\begin{tabular}{llll}
\hline Peak & Identification & UV-vis maxima & MS data APCI (+) and (-) \\
\hline 1 & Zeaxanthin & $427,451,477$ & $569(+) ; 568(-)$ \\
2 & $\beta$-cryptoxanthin & $427,450,477$ & $553(+) ; 552(-)$ \\
3 & $\beta$-carotene & $430,452,478$ & $537(+) ; 536(-)$ \\
4 & $\beta$-cryptoxanthin-laurate (C12:0) & $427,450,477$ & $735,535(+) ; 734(-)$ \\
5 & $\beta$-cryptoxanthin-miristate (C14:0) & $427,450,477$ & $763,535(+) ; 762(-)$ \\
6 & $\beta$-cryptoxanthin-palmitate (C16:0) & $427,450,477$ & $791,535(+) ; 790(-)$
\end{tabular}

Table II.

Carotenoid content $\left(\mu \mathrm{g} \cdot \mathrm{g}^{-1}\right)$ in peach fruit, juice and jam.

\begin{tabular}{llll} 
Compounds & Peach fruits & Peach juice & Peach jam \\
\hline Zeaxanthin & $0.27 \pm 0.12$ & $0.19 \pm 0.02$ & $0.16 \pm 0.03$ \\
$\beta$-cryptoxanthin & $0.12 \pm 0.08$ & $0.26 \pm 0.11$ & $0.32 \pm 0.22$ \\
$\beta$-carotene & $1.98 \pm 0.62$ & $1.61 \pm 0.82$ & $1.42 \pm 0.72$ \\
$\beta$-cryptoxanthin-C12:0 & $0.09 \pm 0.01$ & $0.26 \pm 0.08$ & $0.16 \pm 0.04$ \\
$\beta$-cryptoxanthin-C14:0 & $0.44 \pm 0.04$ & $0.52 \pm 0.04$ & $0.47 \pm 0.06$ \\
$\beta$-cryptoxanthin-C16:0 & $0.07 \pm 0.02$ & $0.20 \pm 0.01$ & $0.16 \pm 0.02$ \\
\hline Mean value of three determinations \pm standard deviation.
\end{tabular}

components among the samples investigated (table II).

Among the free carotenoids, $\beta$-carotene was the most abundant in all the samples analysed, with an average content of $1.98 \mu \mathrm{g} \cdot \mathrm{g}^{-1}$ in the fresh fruits and, respectively, $1.61 \mu \mathrm{g} \cdot \mathrm{g}^{-1}$ and $1.42 \mu \mathrm{g} \cdot \mathrm{g}^{-1}$ in the commercial juice and jam (table II).

Among the monoesters, $\beta$-cryptoxanthin miristate (C14:0) was the most abundant, with, respectively, an average content of $0.44 \mu \mathrm{g} \cdot \mathrm{g}^{-1}, 0.52 \mu \mathrm{g} \cdot \mathrm{g}^{-1}$ and $0.47 \mu \mathrm{g} \cdot \mathrm{g}^{-1}$ in peach fruits, juice and jam (table II).

No data is available in the literature on non-saponified or saponified peach fruit carotenoid extract samples of the variety investigated for a comparison of the carotenoid profile to be made with the results reported in our work. Thus, the results reported here indicate that not only the qualitative carotenoid profile remained similar among the samples, but also that the carotenoid content was not particularly affected during the peach processing for the production of the juice and the jam. Peaches and their products can usefully be included in the range of fruits chosen by consumers to improve their daily consumption of healthy phytochemicals.

\section{References}

[1] Britton G., Liaaen-Jensen S., Pfander H., Carotenoids. Vol. 5: Nutrition and health, Birkhauser Verlag, Basel, Boston, Berl., 2009.

[2] Beutner S., Bloedorn B., Frixel S., Hernandez Blanco I., Hoffman T., Martin H.D., Mayer B., Noack P., Ruck C., Schmidt M., Schulke I., Sell S., Ernst H., Haremza S., Seybold G., Sies H., Stahl W., Walsh R., Quantitative assessment of antioxidant properties of natural colorants and phytochemicals: carotenoids, flavonoids, phenols and indigoids. The role of $\beta$-carotene in antioxidant functions, $\mathrm{J}$. Sci. Food Agric. 81 (2001) 559-568.

[3] Caris-Veyrat C., Antioxidant and prooxidant actions and stabilities of carotenoids in vitro 
and in vivo and carotenoid oxidation products, in: Socaciu C. (Ed.), Food colorants, chemical and functional properties, CRC Press, Taylor \& Francis Group, Boca Raton, Lond., N.Y., 2008.

[4] Arab L., Steck S., Lycopene and cardiovascular disease, Am. J. Clin. Nutr. 71 (2000) 1691S-1695S.

[5] Rao A.V., Rao R.G., Carotenoids and human health, Pharm. Res. 55 (2007) 207-216.

[6] Nishino H., Tokuda H., Satomi, Y., Masuda M., Bu P., Onozuka M., Yamaguchi S., Okuda Y., Takayasu J., Tsuruta J., Okuda M., Ichiishi E., Murakoshi M., Kato T., Misawa N., Narisawa T., Takasuka N., Yano M., Cancer prevention by carotenoids, Pure Appl. Chem. 12 (1999) 2273-2278.

[7] Snodderly M.D., Evidence for protection against age-related macular degeneration by carotenoids and antioxidant vitamins, Am. J. Clin. Nutr. 62 (1995) S1448-S1461.

[8] Krinsky N.I., Johnson E.J., Carotenoid actions and their relation to health and disease, Mol. Aspect Med. 26 (2005) 459516.

[9] Graca Dias M., Oliveira L., Filomena M., Camoes G.F.C., Nunes B., Versloot P., Hulshof P.J.M., Critical assessment of three high performance liquid chromatography analytical methods for food carotenoid quantification, J. Chromatogr. A 1217 (2010) 3494-3502.

[10] Graca Dias M., Filomena M., Camoes G.F.C., Oliveira L., Carotenoids in traditional Portugese fruits and vegetables, Food Chem. 113 (2009) 808-815.

[11] Rodriguez-Amaya D.B., Kimura M., Godoy H., Amaya-Farfan J., Updated Brazilian database on food carotenoids: Factors affecting carotenoids composition, J. Food Comos. Anal. 21 (2008) 445-463.

[12] Sentanin M.A., Rodriguez-Amaya D.B., Carotenoids levels in papaya and peach determined by high performance liquid chromatography, Cienc. Tecnol. Aliment. Campinas 27 (2007) 13-19.

[13] Khachik F., Beecher G.R., Lusby W.R., Separation, identification, and quantification of the major carotenoids in extract of apricots peaches, cantaloupe, and pink grapefruit by liquid chromatography, J. Agric. Food Chem. 37 (1989) 1465-1473.

[14] Van Breemed R.B., Huang C.R., Tan Y., Sander L.C., Schilling A.B., Liquid chromatography/mass spectrometry of carotenoids using atmospheric pressure chemical ionization, J. Mass Spect. 31 (1996) 975-981.

Determinación del perfil de los carotenoides en el fruto, el zumo y la mermelada de melocotón.

Resumen - Introducción. Se describieron los carotenoides como tenedores de varias propiedades importantes funcionales y de efectos positivos para la salud. Dichas propiedades hacen que estos compuestos sean ideales para la industria alimentaria funcional, en incesante crecimiento, así como para la promoción del consumo de los productos naturales, de los cuales forman parte. Anotamos aquí la primera caracterización de la composición de los carotenoides no saponificados en los melocotones frescos y en los zumos y mermelada de melocotón comerciales. Material y métodos. Se compraron en el mercado local melocotones amarillos en plena madurez, producidos en Sicilia; se pelaron, y, a continuación, se analizó su pulpa. Asimismo, se compraron en el mercado local zumo y mermelada de melocotón de origen comercial, procedentes de tres diferentes fábricas conocidas. El zumo y la mermelada analizados se produjeron por fabricantes locales, a partir del mismo tipo de fruto que los frutos frescos estudiados por separado. Tras extracción de los carotenoides con la ayuda de disolventes orgánicos, se analizaron las muestras por un método directo de HPLC-DAD-APCIMS. Resultados y discusión. Se identificaron tres carotenoides libres (zeaxantina, $\beta$-criptoxantina y $\beta$-caroteno) y tres monoésteres de $\beta$-criptoxantina; y se detectaron en todas las muestras analizadas. Un hecho interesante: el perfil de los carotenoides permaneció igual en todas las muestras y no se vio afectado por la transformación de los frutos durante la producción del zumo y de la mermelada de melocotón. Además, se observaron pequeñas diferencias en los contenidos relativos de los compuestos identificados en las muestras estudiadas.

Italia / Prunus persica / durazno / jugo de frutas / mermeladas / cromatografía / composición aproximada / carotenoides 